\title{
Predictive factors of the interruption of exclusive breastfeeding in premature infants: a prospective cohort
}

\author{
Fatores preditivos da interrupção de aleitamento materno exclusivo em prematuros: coorte prospectiva
}

Factores predictivos de la interrupción de la lactancia materna exclusiva en prematuros: cohorte prospectiva

Lucyana Silva Luz', Ruth Minamisava', Carmen Gracinda Silvan Scochi",
Ana Karina Marques Salge', Laiane Medeiros Ribeiro"', Thaíla Corrêa Castral'
'Universidade Federal de Coiás, School of Nursing. Coiânia, Goiás, Brazil.
"Universidade de São Paulo, School of Nursing of Ribeirão Preto. Ribeirão Preto, São Paulo, Brazil.
"' Universidade de Brasilia. Ceilandia, Distrito Federal, Brazil.

How to cite this article:

Luz LS, Minamisava R, Scochi CGS, Salge AKM, Ribeiro LM, Castral TC. Predictive factors of the interruption of exclusive breastfeeding in premature infants: a prospective cohort. Rev Bras Enferm [Internet]. 2018;71(6):2876-82.

DOI: http://dx.doi.org/10.1590/0034-7167-2017-0762

\section{Submission: 10-31-2017 Approval: 02-15-2018}

\section{ABSTRACT}

Objective: to evaluate the incidence of exclusive breastfeeding and the risk factors associated to its interruption in premature infants after hospital discharge. Method: this is a prospective cohort with 113 premature infants in a neonatal unit, whom were followed-up from 7 to 15 days after hospital discharge. The outcome was the interruption of exclusive breastfeeding. Maternal and neonatal exposure variables were evaluated by a regression model and described by the confidence interval $(95 \%)$ and risk ratio. Results: exclusive breastfeeding rate was $81.4 \%$ at discharge and $66.4 \%$ at 7 to 15 days after discharge. Double gestation, time of mechanical ventilation and birth weight were associated with higher risks of interruption of exclusive breastfeeding after discharge. Conclusion: there is a need for the implementation of actions that promote the early onset and maintenance of exclusive breastfeeding of premature infants.

Descriptors: Premature; Breast Feeding; Neonatal Intensive Care Unit; Patient Discharge; Cohort Studies.

\section{RESUMO}

Objetivo: Avaliar a incidência do aleitamento materno exclusivo e os fatores de risco associados à interrupção de aleitamento materno exclusivo em prematuros após a alta hospitalar. Método: Coorte prospectiva com 113 prematuros em unidade neonatal, e acompanhados entre 7 e 15 dias após a alta hospitalar. Teve-se como desfecho a interrupção do aleitamento materno exclusivo. As variáveis de exposição maternas e neonatais foram avaliadas por meio do modelo de regressão e descritas pela razão de risco e intervalo de confiança (95\%). Resultados: A incidência de aleitamento materno exclusivo foi de $81,4 \%$ na alta e $66,4 \%$ entre 7 e 15 dias após a alta. As variáveis gestação dupla, tempo de ventilação e peso ao nascer foram associadas a um maior risco de interrupção do aleitamento materno exclusivo após a alta. Conclusão: É necessária a implementação de ações que promovam o início precoce e manutenção do aleitamento materno exclusivo no prematuro.

Descritores: Prematuro; Aleitamento Materno; Unidades de Terapia Intensiva Neonatal; Alta do Paciente; Estudos de Coortes.

\section{RESUMEN}

Objetivo: evaluar la incidencia de la lactancia materna exclusiva y los factores de riesgo asociados a su interrupción en prematuros después del alta hospitalaria. Método: cohorte prospectiva con 113 prematuros en unidad neonatal, acompañados de 7 a 15 días después del alta hospitalaria. El resultado fue la interrupción de la lactancia materna exclusiva. Las variables de exposición materna y neonatal fueron evaluadas por medio del modelo de regresión y descritas por la razón de riesgo e intervalo de confianza (95\%). Resultados: la incidencia de lactancia materna exclusiva fue del $81,4 \%$ en la alta y del $66,4 \%$ entre 7 y 15 días después del alta. Las variables gestación doble, tiempo de ventilación y peso al nacer se asociaron a un mayor riesgo de interrupción de la lactancia materna exclusiva después del alta. Conclusión: es necesaria la implementación de acciones que promuevan el inicio precoz y el mantenimiento de la lactancia materna exclusiva del prematuro.

Descriptores: Recien Nacido Prematuro; Lactancia Materna; Unidades de Cuidado Intensivo Neonatal; Alta del Paciente; Estudios de Cohortes. 


\section{INTRODUCTION}

Exclusive breastfeeding (EBF) is an effective and inexpensive intervention that can reduce thousands of neonatal deaths ${ }^{(1-2)}$. The prevalence of EBF until five months of age is higher in lowand middle-income countries than in high-income countries. The gross domestic product ratio is inversely proportional to the prevalence of breastfeeding until 12 months of age ${ }^{(2)}$. Brazil is a middle to high-income country and has great heterogeneity among its regions, being internationally recognized for successful policies in support, protection and promotion of breastfeeding, with emphasis on the wide deployment of the Baby Friendly Hospital Initiative (BFHI), on the effectiveness of the Human Milk Banks Network and on the creation of the Brazilian Standard for the Commercialization of Food for Infants and Children, Nozzles, Pacifiers and Feeding Bottles (NBCAL - Norma Brasileira de Comercialização de Alimentos para Lactentes e Crianças de Primeira Infância, Bicos, Chupetas e Mamadeiras) (Brasil, 2006).

A meta-analysis study showed that breastfeeding reduces neonatal deaths in $12 \%$ to $36 \%$. In addition, it reduces the necrotizing enterocolitis rate in $58 \%$, provides protection for half the cases of diarrhea and a third of respiratory infections. The chances of otitis media are reduced in $0.67 \%$ to $1.21 \%$, and of asthma in $9 \%$. In the long run, breastfeeding is associated to a $26 \%$ reduction in the chance of overweight or obesity, $35 \%$ in the chance of type 2 diabetes and $19 \%$ in childhood leukemia. Furthermore, breastfeeding is associated to better performance on intelligence tests in children and adolescents and to higher wages in adult life ${ }^{(2)}$. Breastfeeding also offers benefits to the mother, such as decrease in postpartum hemorrhage, reduced weight gain in pregnancy, strengthening of the mother-child bond and decreased risk of breast cancer ${ }^{(3)}$.

However, breastfeeding a premature infant is a difficult process due to unstable conditions, physiological immaturity which is specific for this population and hospitalization itsel $f^{(4-5)}$. Hindrances for the early onset of breastfeeding include the non-continuous stay of mothers in the neonatal unit, the low frequency of the kangaroo method, the inconsistent professional support and familial dysfunction ${ }^{(6-7)}$.

Human milk is the best food for premature infants. The milk from mothers of pre-term infants has high concentrations of lactoferrin, lysozyme and immunoglobulin A, these concentrations are different from the milk of mothers of full-term infants. This factor is extremely important for the appropriate development and brain growth, considering the increased nutrients need of premature infants ${ }^{(8)}$.

Despite the many benefits of breastfeeding, this practice is still not universally spread, including in Brazil. According to the United Nations Children's Fund (Unicef), less than 40\% of infants under six months are exclusively breastfed in the world ${ }^{(9)}$. According to the latest survey conducted in Brazilian capitals and Federal District in 2008, among 34,366 children, the prevalence of EBF in infants under six months was $41 \%{ }^{\left({ }^{8}\right)}$. In premature infants, three cohorts in the Southern region of Brazil have reported a prevalence of $28.4 \%$ to $70.5 \%$ at hospital discharge, and $16.4 \%$ to $35.7 \%$ at six months of age ${ }^{(10-11)}$.
The strategies of the World Health Organization (WHO) to increase EBF rates until 2025 include the revitalization, expansion and institutionalization of the BFHI; the implementation of strategies to support breastfeeding in communities; the significant reduction of aggressive and inappropriate marketing of breast milk substitutes (formulas); the empowerment of women to breastfeed exclusively until the infant is six months of age; and the investment in professional training for protection, promotion and support of breastfeeding ${ }^{(12)}$.

The monitoring of EBF rates is a critical health indicator for planning, implementing and assessing initiatives that promote breastfeeding, such as the BFHI. Therefore, this study followed premature infants from the Center-West region of Brazil, described EBF rates before the maternity ward receive the title of "Baby Friendly Hospital", and investigated the factors that contributed to the interruption of EBF after hospital discharge. These findings are of great relevance for comparison with premature infant samples in Brazil and in other countries, given the difficulty to follow-up this population. Thus, the objective was to evaluate EBF rates and the risk factors associated with the interruption of EBF in the second week after hospital discharge.

\section{OBJECTIVE}

To evaluate the incidence of exclusive breastfeeding and the risk factors associated to its interruption in premature infants after hospital discharge.

\section{METHOD}

\section{Ethical aspects}

This study met the Brazilian ethical standards in research, being approved by the Research Ethics Committee of the Hospital das Clínicas da Universidade Federal de Goiás (HC-UFG). All mothers or guardians (in the case of adolescent mothers) signed an informed consent form.

\section{Study design, location and period}

This is a prospective open cohort study, conducted in the neonatal unit of a public maternity ward in Goiânia (GO), CenterWest region of Brazil, from April 15t, 2014 to April 1st, 2015. The maternity ward has a neonatal unit with ten intensive beds, ten intermediate beds and five beds of the kangaroo method.

\section{Sample, inclusion and exclusion criteria}

Were included, premature infants with gestational age under 37 weeks, which was obtained through Capurro's somatic method, registered in medical records, and the premature infants admitted in the neonatal unit within the first 48 hours of life, with minimum length of stay of 48 hours. Were excluded, premature infants whose mothers or their children had temporary or definitive contraindication to breastfeeding (positive HIV/aids, human T-cell lymphotropic virus, untreated syphilis or tuberculosis, gastroesophageal reflux disease, phenylketonuria, galactosemia etc. $)^{(13)}$, cases of maternal or infant's death and premature infants whom were transferred to another hospital. 
The study sample consisted of all premature infants admitted in the neonatal unit of the institution between April 1 ${ }^{\text {st }}, 2014$ and April 1 ${ }^{\text {st }}, 2015$. During the data collection period, 218 premature infants were admitted in the neonatal unit and, of these, 133 met the inclusion criteria. After hospital discharge there were 20 losses (15\%), totaling 113 participants in the study, as detailed in (Figure 1).

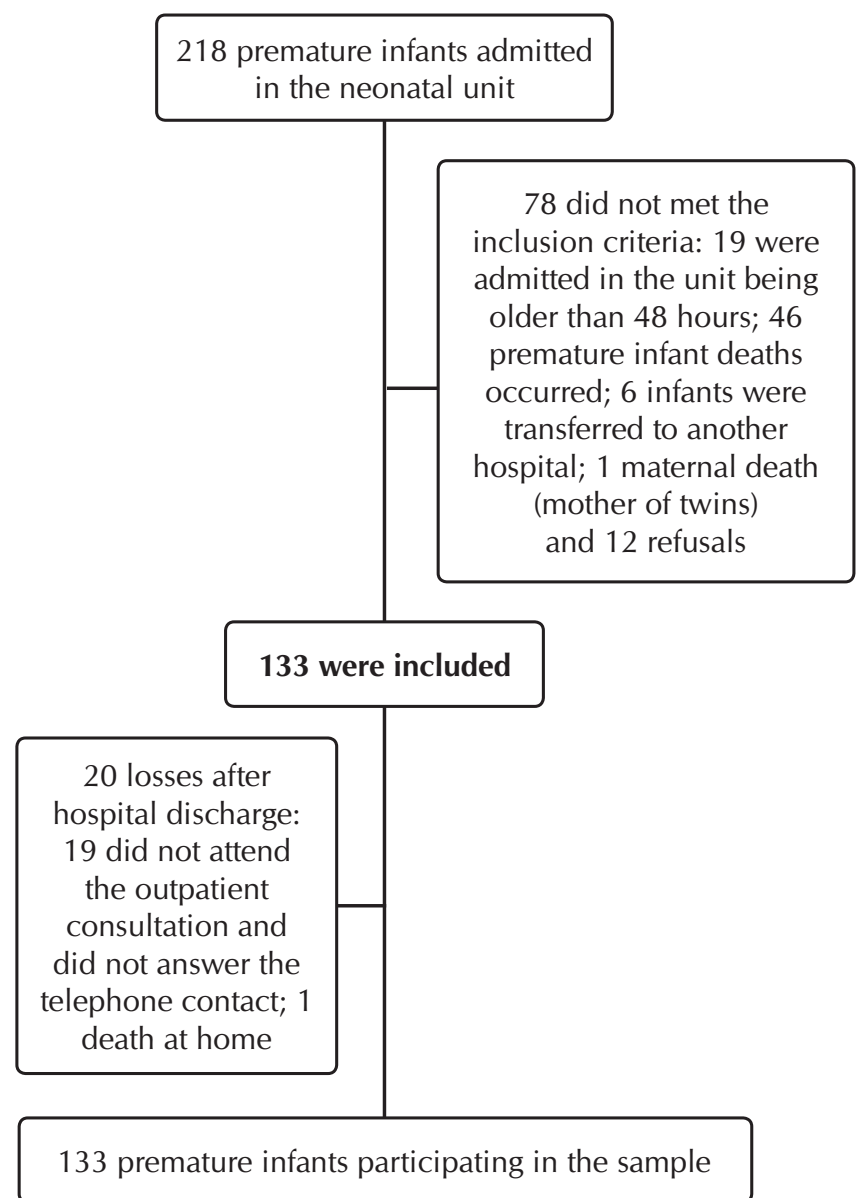

Figure 1 - Flowchart of recruitment and follow-up study, Goiânia, Goiás, Brazil, 2014-2015

\section{Study protocol}

The interruption of EBF of the premature infants between 7 to 15 days after hospital discharge was the outcome variable. Thus, the introduction of any food, in addition to breast milk, was considered as interruption of EBF.

Recruitment of participants was conducted from the premature infants' discharge records in the neonatal unit, and those whom were eligible had their data collected retrospective and prospectively, and through an interview on an outpatient consultation. The outpatient consultation occurred between 7 to 15 days after hospital discharge, breastfeeding data were collected in this moment. A semi-structured questionnaire was used for the interview, being elaborated from a literature review and suggestions from breastfeeding researchers. The questionnaire was validated in a pilot study in other neonatal units. The questionnaire was filled by the researchers and a trained research assistant.
Breastfeeding was classified as EBF (only breast milk, with the exception of medicines, mineral supplements, vitamins and oral rehydration solutions), prevailing breastfeeding (introduction of water or water-based beverages such as juice, infusions and teas, in addition to breast milk), breastfeeding (breast milk directly or milked, regardless of receiving or not other food) and partial or mixed breastfeeding (introduction of other types of milk, in addition to human milk) ${ }^{(1)}$. The infant's gestational age in weeks was classified as: extreme (greater than 28 weeks); moderate (from 28 to 31 weeks); and borderline (from 32 to 37 weeks).

\section{Data analysis}

Questionnaire data were entered into a spreadsheet in the software Statistical Package for the Social Sciences (SPSS ${ }^{\circledR}$, version 21.0), being analyzed for data consistency. Descriptive (frequency, mean and standard deviation) and univariate and multiple inferential analysis of data were conducted, as well as Cox's proportional-hazards regression. The measure for association was the hazard risk (HR), using 95\% confidence intervals. Variables with $p<0.10$ in univariate analyses were included in the backward multiple regression model. For all analyses, $p$ $<0.05$ was considered significant.

In inferential analysis, the interruption of EBF was considered the outcome variable among premature infants, and as potential predictive maternal variables: mother with extreme age, maternal education, parents who live together, family income, prior experience with breastfeeding, primiparous, breast problems, having undergone six or more prenatal consultations; and for neonatal: twin gestation, delivery type, birth weight, gestational age, sex, time in invasive and non-invasive ventilation support, hospitalization time, first milk feeding within 24 hours, having sucked on the breast in the first week of life, EBF at hospital discharge. The infant's age on the return consultation was established as the time variable.

\section{RESULTS}

The mean age of mothers was $26(\mathrm{SD}=6.7)$ years, most of them were in consensual relationships (52.2\%), and $89.4 \%$ lived with the infant's father. Among premature infants, $52.2 \%$ were male, $82.3 \%$ were born from single gestation, $71.7 \%$ were delivered by Cesarean section, and $47.8 \%$ required resuscitation at birth. The mean gestational age was $32.2(S D=20.6)$ weeks, and $72(63.7 \%)$ premature infants had between 32 and 37 gestational weeks. Among the premature infants, 61 (54.0\%) were hospitalized for less than 30 days. The mean total time of hospitalization was 35 (SD = 28.3) days, and $94(83.2 \%)$ infants were hospitalized in the neonatal intensive care unit, $104(92.0 \%)$ in the neonatal intermediate care unit, and 78 $(69.0 \%)$ in the kangaroo unit. Most premature infants required ventilation support $(92.0 \%) ; 83.2 \%$ remained in mechanical ventilation support for less than seven days. The mean time of ventilation was $4.9(\mathrm{SD}=9.6)$ days.

Table 1 describes the infant's type of breastfeeding at hospital discharge, and at the second week (between 7 to 15 days) after hospital discharge. 
Table 1 - Feeding characteristics of premature infants during hospitalization, at hospital discharge and at home, Goiânia, Goiás, Brazil, 2014-2015

\begin{tabular}{lcc}
\hline \multicolumn{1}{c}{ Type of breastfeeding } & $\mathbf{f} \neq$ & \%\# \\
\hline Hospital discharge & & \\
$\quad$ Exclusive Breastfeeding & 92 & 81.4 \\
Breastfeeding & 15 & 13.3 \\
Bottle feeding & 5 & 4.4 \\
Prevailing Breastfeeding & 1 & 0.9 \\
Second week after hospital discharge & & \\
Exclusive Breastfeeding & 75 & 66.4 \\
Breastfeeding & 19 & 16.8 \\
Prevailing Breastfeeding & 11 & 9.7 \\
Bottle feeding & 8 & 7.1 \\
\hline
\end{tabular}

Note: $\ddagger$ absolute frequency, \# relative frequency.

Table 2 - Potential maternal and neonatal predictive factors of the interruption of exclusive breastfeeding at the second week after hospital discharge, Goiânia, Goiás, Brazil, 2014-2015

\begin{tabular}{|c|c|c|c|c|c|}
\hline \multirow{3}{*}{ Exposure variables } & \multicolumn{4}{|c|}{ Exclusive Breastfeeding } & \multirow{3}{*}{$\underset{\text { value* }}{p}$} \\
\hline & \multicolumn{2}{|c|}{ No } & \multicolumn{2}{|c|}{ Yes } & \\
\hline & $f \neq$ & $\% \#$ & $f \neq$ & $\% \#$ & \\
\hline \multicolumn{6}{|l|}{ MATERNAL } \\
\hline \multicolumn{6}{|l|}{$\begin{array}{l}\text { Mother with extreme age } \\
\text { ( } \leq 18 \text { or } \geq 35 \text { years) }\end{array}$} \\
\hline Yes & 12 & 32.4 & 25 & 67.6 & 0.974 \\
\hline No & 26 & 34.2 & 50 & 65.8 & \\
\hline \multicolumn{6}{|l|}{ Maternal education } \\
\hline Up to High School & 26 & 31.3 & 57 & 68.7 & 0.367 \\
\hline Higher Education & 12 & 40.0 & 18 & 60.0 & \\
\hline \multicolumn{6}{|l|}{ Parents live together } \\
\hline No & 4 & 33.3 & 8 & 66.7 & 0.267 \\
\hline Yes & 34 & 33.7 & 67 & 66.3 & \\
\hline \multicolumn{6}{|l|}{ Primípara } \\
\hline Yes & 19 & 31.1 & 42 & 68.9 & 0.181 \\
\hline No & 19 & 36.5 & 33 & 63.5 & \\
\hline \multicolumn{6}{|l|}{$\begin{array}{l}\text { Underwent six or more } \\
\text { prenatal consultations }\end{array}$} \\
\hline No & 14 & 34.1 & 27 & 65.9 & 0.296 \\
\hline Yes & 24 & 33.3 & 48 & 66.7 & \\
\hline \multicolumn{6}{|l|}{$\begin{array}{l}\text { Prior experience with } \\
\text { breastfeeding }\end{array}$} \\
\hline No & 29 & 37.2 & 49 & 62.8 & 0.525 \\
\hline Yes & 9 & 25.7 & 26 & 74.3 & \\
\hline \multicolumn{6}{|l|}{$\begin{array}{l}\text { There were problems with } \\
\text { the breasts }\end{array}$} \\
\hline Yes & 2 & 8.3 & 22 & 91.7 & $0.070 *$ \\
\hline No & 36 & 40.4 & 53 & 59.6 & \\
\hline \multicolumn{6}{|l|}{ Double gestation } \\
\hline Yes & 12 & 60.0 & 8 & 40.0 & $0.002 *$ \\
\hline No & 26 & 28.0 & 67 & 72.0 & \\
\hline \multicolumn{6}{|l|}{ Delivery type } \\
\hline Cesarean section & 29 & 35.8 & 52 & 64.2 & 0.219 \\
\hline Vaginal & 9 & 28.1 & 23 & 71.9 & \\
\hline \multicolumn{6}{|l|}{ NEONATAL } \\
\hline \multicolumn{6}{|l|}{ Gender } \\
\hline Female & 16 & 29.6 & 38 & 70.4 & 0.330 \\
\hline Male & 22 & 37.3 & 37 & 62.7 & \\
\hline
\end{tabular}

Table 2 (concluded)

\begin{tabular}{|c|c|c|c|c|c|}
\hline \multirow{3}{*}{ Exposure variables } & \multicolumn{4}{|c|}{ Exclusive Breastfeeding } & \multirow{3}{*}{$\underset{\text { value }^{*}}{p}$} \\
\hline & \multicolumn{2}{|c|}{ No } & \multicolumn{2}{|c|}{ Yes } & \\
\hline & $f \neq$ & $\% \#$ & $f \neq$ & $\% \#$ & \\
\hline \multicolumn{6}{|l|}{ Gestational age at birth } \\
\hline$<28$ - extreme & 3 & 37.5 & 5 & 62.5 & $0.000 *$ \\
\hline 28-31 - moderate & 13 & 39.4 & 20 & 60.6 & $0.000^{*}$ \\
\hline 32-37 - borderline & 22 & 30.6 & 50 & 69.4 & \\
\hline \multicolumn{6}{|l|}{ Hospitalization time } \\
\hline$>30$ days & 24 & 46.2 & 28 & 53.8 & $0.014^{*}$ \\
\hline$\leq 30$ days & 14 & 23.0 & 47 & 77.0 & \\
\hline \multicolumn{6}{|l|}{ Ventilation time } \\
\hline$>7$ days & 8 & 42.1 & 11 & 57.9 & $0.001^{*}$ \\
\hline 7 days & 30 & 31.9 & 64 & 68.1 & $<=$ \\
\hline \multicolumn{6}{|l|}{ Age of first milk feeding } \\
\hline$>24$ hours & 18 & 46.2 & 21 & 53.8 & 0.306 \\
\hline$\leq 24$ hours & 20 & 27.0 & 54 & 73.0 & \\
\hline
\end{tabular}

Sucked on the breast on the first week of life

$\begin{array}{llllll}\text { No } & 26 & 40.0 & 39 & 60.0 & 0.000^{*} \\ \text { Yes } & 12 & 25.0 & 36 & 75.0 & \end{array}$

Exclusive breastfeeding at discharge

$\begin{array}{lccccc}\text { No } & 20 & 95.2 & 1 & 4.8 & 0.112 \\ \text { Yes } & 18 & 19.6 & 74 & 80.4 & \end{array}$

\begin{tabular}{lccccc}
\hline & Mean & SD\# & Mean & SD। & $\begin{array}{c}\boldsymbol{p} \\
\text { value* }\end{array}$ \\
\hline Household income (BRL) & 1.762 .8 & 9 & 1.983 .0 & & 0.881 \\
Birth weight (in grams) & 1.452 & 454.0 & 1.686 & 565.0 & $0.000^{*}$ \\
\hline
\end{tabular}

Note: $\neq$ f absolute frequency, $\# \%$ relative frequency, ${ }^{*} p<0.10,{ }^{* *}$ standard deviation.

Table 3 - Maternal and neonatal predictive factors of the interruption of exclusive breastfeeding at the second week after hospital discharge, Goiânia, Goiás, Brazil, 2014-2015

\begin{tabular}{|c|c|c|c|c|}
\hline Variables & Beta & $\underset{\text { value }}{p}$ & $\begin{array}{c}\text { Adjusted } \\
\text { hazard } \\
\text { risk }\end{array}$ & $\begin{array}{c}\text { Confidence } \\
\text { interval } \\
(95 \%)\end{array}$ \\
\hline $\begin{array}{l}\text { Problems with the } \\
\text { breasts }\end{array}$ & -1.362 & 0.071 & 0.256 & 0.058 a 11.213 \\
\hline Double gestation & 1.503 & $0.001^{*}$ & 4.495 & 1.802 a 11.213 \\
\hline \multicolumn{5}{|l|}{ Gestational age at birth } \\
\hline$<28$ weeks & -1.391 & 0.106 & 0.249 & 0.046 a 1.344 \\
\hline 28-31 weeks & -0.163 & 0.788 & 0.849 & 0.258 a 2.707 \\
\hline \multicolumn{5}{|l|}{ 32-37 weeks } \\
\hline Birth weight (in grams) & 0.001 & $0.038^{*}$ & 1.001 & 1.000 a 1.002 \\
\hline Hospitalization time & -12.128 & 0.882 & 0.000 & 0.000 a 2.367 \\
\hline Ventilation time & -1.941 & $0.016^{*}$ & 0.144 & 0.030 a 0.694 \\
\hline Gender & -0.385 & 0.297 & 0.680 & 0.330 a 1.403 \\
\hline $\begin{array}{l}\text { Sucked on the breast on } \\
\text { the first week of life }\end{array}$ & -0.606 & 0.284 & 0.545 & 0.180 a 1.654 \\
\hline
\end{tabular}

Note: ${ }^{*} p<0.05$ 
The results of the univariate analysis of potential maternal and neonatal predictive factors of the interruption of EBF at the second week after hospital discharge, at home, are shown in Table 2.

Statistically significant variables $(p<0.10)$ in univariate analysis composed the model for multivariate analysis (Table 3 ).

\section{DISCUSSION}

This study found incidence of EBF in $81.4 \%$ premature infants at hospital discharge, and $66.4 \%$ at the return consultation, in the second week after hospital discharge ( 7 to 15 days). These indices can be considered acceptable according to the WHO's recommendations, but are still below the recommended $90 \%{ }^{(14)}$.

Two other cohorts conducted with premature infants in Brazil found EBF rates than in our study. The first cohort, conducted with 116 premature infants in Porto Alegre (RS), found $36.2 \%$ EBF incidence after 14 days, and 25\% after 28 days of hospital discharge ${ }^{(10)}$. The second cohort comprised 42 premature infants from Maringá (PR), found 71.5\% EBF after 15 days of discharge ${ }^{(15)}$. In Denmark, a cohort conducted with 1,488 premature infants found the EBF rate to be $68 \%$ at hospital discharge, with a significant drop to $13 \%$ at six months of age ${ }^{(16)}$. Despite the differences between the evaluation periods of the studies, we found the existence of a difficulty in establishing and maintaining EBF, especially after hospital discharge.

The maternity ward that served as the object of this study was awarded the title of "Baby Friendly Hospital" in April 2016, after the end of the data collection; however, since its creation in 2012, practices to promote, protect and support breastfeeding were established. Additionally, the institution also has a room for human milk collection and a partnership with a human milk bank; furthermore, the three stages of the kangaroo method have been implemented.

The title of "Baby Friendly Hospital" can contribute to better EBF indices at discharge, however, the practices conducted in the hospital for breastfeeding do not ensure the maintenance of these indices after discharge ${ }^{(17)}$. In addition, the guidelines of the initiative do not consider the particularities of premature infants and the difficulties generated by the very process of hospitalization in a neonatal unit.

The incidence of EBF reduced in 15\% between hospital discharge and home. Other Brazilian studies also point to drops in EBF rates after the infant's discharge $\mathrm{e}^{(10-11,15,18)}$. These data are concerning due to pointing a failure of current policies and practices that seek to maintain breastfeeding after the infant's discharge.

In this study, higher birth weight, double gestation and shorter time on mechanical ventilation (invasive and non-invasive) were associated with higher risks of interrupting exclusive breastfeeding. We must highlight that these variables can influence early weaning independently. Other cohorts with newborns (pre-term and term) also found association between the interruption of exclusive breastfeeding and weight ${ }^{(19)}$, time in ventilation support $^{(15,20-21)}$ and double gestation ${ }^{(18,22)}$.

These data lead to recommendations for clinical practice. Gestational age should not be a barrier for breastfeeding. The literature presents no standardized criteria regarding the start of breastfeeding in premature infants. Evidence from the literature show that a premature infant can start being breastfed when he/ she is stable and has no contraindications to breastfeeding, and this is the only criterion to be adopted ${ }^{(23)}$. In this case, stability is defined when the infant does not present severe apnea, bradycardia and desaturation in routine care $^{(23)}$.

Neonatal morbidity is inversely proportional to gestational age and birth weight. These factors are critical for the infant's survival ${ }^{(19)}$. Therefore, we believe that birth weight and gestational age are important variables in the context of the feeding of premature infants but should not be considered as isolated factors for the onset and maintenance of infants' breastfeeding.

The fact that our findings showed that premature infants with higher birth weight had higher chances of interrupting EBF at home was surprising. However, these infants were hospitalized in the maternity ward for less time, consequently, having less support from trained professionals. Therefore, it must be considered that these infants face higher risks of weaning; therefore, mothers must receive adequate support before discharge, as well as specialized outpatient follow-up, articulating it with the care provided by primary health care professionals.

The feeding of premature infants in mechanical ventilation usually occurs through nasogastric tube, but its prolonged use may cause phono-articulatory damages ${ }^{(19)}$. In addition, lactating mothers present insecurity when they see their child in incubators, intubated and using mechanical ventilation. The premature infant's mother must be counseled and stimulated by the team of the neonatal unit to perform early milking (which must be initiated within six hours after delivery) $)^{(23)}$ so she can offer her child her own milk while he/she is under mechanical ventilation and being fed by tube. In addition, techniques like non-nutritive sucking and trans-lactation must be used to reduce the time of transition to oral feeding. Thus, the smaller the time on mechanical ventilation, the smaller the chance of early weaning of the infant.

Exclusively breastfeeding in twins is a huge challenge. In Japan, a study with 15,262 infants born at term between three and six months of age, found $4.1 \%$ of EBF prevalence in twins when compared to $44.7 \%$ in non-twins. Mothers of twins were 2.4 times more likely to choose the bottle and formula ${ }^{(22)}$. In Sweden, a cohort of twin infants born at term $(n=962)$ and pre-term $(n=695)$ found that pre-term twins have a higher risk of weaning at two $(\mathrm{OR}=1.36 ; 95 \% \mathrm{Cl}=1.06-1.75)$, four $(\mathrm{OR}$ $=1.28 ; 95 \% \mathrm{Cl}=1.05-1.57)$, $\operatorname{six}(\mathrm{OR}=1.30 ; 95 \% \mathrm{Cl}=1.06-$ $1.58)$ and nine $(\mathrm{OR}=1.43 ; 95 \% \mathrm{Cl}=1.09-1.88)$ months of age. Lower education level and smoking were associated with higher risk of weaning among premature twins ${ }^{(22)}$.

A qualitative study with mothers of twins showed that the mothers interpret babies crying as insufficiency of breast milk. Other difficulties raised were the difficulty of suction, fatigue and insufficient guidance received from health professionals during hospitalization ${ }^{(24)}$.

Most of the time, twins are premature and/or have low birth weight, which makes breastfeeding fundamental for their development. The guidance by professionals trained in breastfeeding is critical, during pregnancy, childbirth and puerperium, for the onset and maintenance of breastfeeding. Furthermore, mothers 
of twins need a support network, so they can share household and baby care tasks, in addition to having guaranteed access to and support from health care services to solve breastfeedingrelated problems after hospital discharge.

\section{Study limitations}

The monitoring of premature infants up to 15 days after hospital discharge, at home, was a limitation of this study, given that in the first two weeks at home, clinical factors (such as mechanical ventilation and birth weight) could still exert more influence than cultural factors (such as the desire to breastfeed, not working, residing with the partner). Monitoring the premature infants until six months of corrected age, or even until the interruption of EBF, would better elucidate all factors involved in the maintenance of EBF.

\section{Contributions to the field of nursing}

The various difficulties of premature infants in breastfeeding, which have already been documented in the literature, as well as the decrease in the incidence of EBF after the hospital discharge reported in this study, point to the need for specialized nursing care to ensure the early onset and maintenance of breastfeeding in this vulnerable population. These results may subsidize the elaboration of specific recommendations and health policies for premature infants, based on robust scientific evidence, including the context of hospitalization in neonatal unit. We consider that the Neonatal BFHI (BFHI-Neo) is a promising initiative to improve the breastfeeding practices of premature infants, as well as the EBF rates during and after hospital discharge.

\section{CONCLUSION}

The incidence of EBF among the studied premature infants was $81.4 \%$ at hospital discharge and $66.4 \%$ at home, representing a $15 \%$ drop in EBF rates in the second week after hospital discharge. These findings show the difficulty of establishing the EBF among premature infants until hospital discharge, as well as its maintenance at home.

Double gestation, time of ventilation support and birth weight were predictive factors of the interruption of EBF in premature infants after hospital discharge. Thus, health professionals must provide greater assistance to mothers and premature twins whom remain under mechanical ventilation for more than seven days and have higher birth weight, to prevent the early interruption of EBF.

The multidisciplinary team must implement health care actions based on scientific evidence for premature infants - such as the NFHI-Neo -, promoting the early onset and maintenance of breastfeeding during hospitalization in neonatal units, in addition to the articulation of these actions with primary health care so EBF can be maintained at home until the infant reaches six months of age. These actions must be supported by public policies and scientific evidence, considering the specific characteristics of premature infants in the context of neonatal units.

\section{REFERENCES}

1. World Health Organization-WHO. Indicators for assessing infant and young child feeding practices: conclusions of a consensus meeting held 6-8 November 2007 in Washington D.C., USA[Internet]. Geneva: World Health Organization; 2008[cited 2016 Jul 19]. 19 p. Available from: http://www.who.int/nutrition/publications/iycf_indicators_for_peer_review.pdf

2. Victoria CG, Bahl R, Barros AJ, França GV, Horton S, Krasevec J, et al. Breastfeeding in the 21st century: epidemiology, mechanisms, and lifelong effect. Lancet[Internet]. 2016[cited 2016 Sep 3];387(10017):475-90. Available from: http://www.thelancet.com/journals/ lancet/article/PIIS0140-6736(15)01024-7/abstract

3. Gradim CVC, Magalhães MC, Faria MCF, Arantes CIS. Aleitamento materno como fator de proteção para o câncer de mama. Rev Rene[Internet]. 2011[cited 2016 Sep 3];12(2):358-64. Available from: http://periodicos.ufc.br/rene/article/view/4220

4. World Health Organization-WHO. Born too soon: the global action report on preterm birth[Internet]. Geneva: World Health Organization; 2012[cited 2016 Aug 3]. 126 p. Available from: http://apps.who.int/iris/bitstream/10665/44864/1/9789241503433 eng.pdf?ua $=1$

5. Rodrigues AP, Martins EL, Trojahn TC, Padoin SMM, Paula CC, Tronco CS. Manutenção do aleitamento materno de recém-nascidos pré-termo: revisão integrativa da literatura. Rev Eletrôn Enferm[Internet]. 2013[cited 2016 Sep 3];15(1):253-64. Available from: https://www.fen.ufg.br/fen_revista/v15/n1/pdf/v15n1a29.pdf

6. Ikonen R, Paavilainen E, Kaunonen M. Preterm infants' mothers' experiences with milk expression and breastfeeding: an integrative review. Adv Neonatal Care[Internet]. 2015[cited 2018 Aug 13];15(6):394-406. Available from: https://insights.ovid. com/pubmed?pmid $=26536173$

7. Smith R, Lucas R. Evaluation of nursing knowledge of early initiation of breastfeeding in preterm infants in a hospital setting. J Neonatal Nurs[Internet]. 2016[cited 2018 Aug 13];22(3):138-43. Available from: https://www.journalofneonatalnursing.com/article/ S1355-1841(15)00114-3/abstract

8. Kumar RK, Singhal A, Vaidya U, Banerjee S, Anwar F, Rao S. Optimizing nutrition in preterm low birth weight infants-consensus summary. Front Nutr[Internet]. 2017[cited 2018 Jan 22];4(20):1-9. Available from: https://www.frontiersin.org/articles/10.3389/ fnut.2017.00020/full

9. United Nations Children's Fund. Unicef global databases, 2016, based on MICS, DHS and other nationally representative sources, 2010-2014[Internet]. New York: United Nations Children's Fund; 2016[cited 2016 Jul 19]. Available from: http://data.unicef.org/ 
nutrition/iycf.html\#sthash.nEsKwT3U.dpuf

10. Azevedo M, Cunha MLC. Fatores associados ao aleitamento materno exclusivo em prematuros no primeiro mês após a alta hospitalar. Rev HCPA[Internet]. 2013[cited 2016 Sep 3];33(1):40-9. Available from: http://seer.ufrgs.br/hcpa/article/view/37653

11. Silva PK, Almeida ST. Avaliação de recém-nascidos prematuros durante a primeira oferta de seio materno em uma UTI neonatal. Rev Cefac[Internet]. 2015[cited 2016 Sep 3];17(3):927-35. Available from: http://www.scielo.br/pdf/rcefac/v17n3/1982-0216rcefac-17-03-00927.pdf

12. World Health Organization-WHO. United Nations Children's Fund. Global nutrition targets 2025: breastfeeding policy brief. Geneva: World Health Organization; 2014. 8 p.

13. Brasil. Ministério da Saúde. Manual normativo para profissionais de saúde de maternidades: referência para mulheres que não podem amamentar. Brasília: Ministério da Saúde; 2005. 32 p.

14. World Health Organization-WHO. Exclusive breastfeeding for six months best for babies everywhere. Geneva: World Health Organization; 2011 [cited 2016 Jul 19]. Available from: http://www.who.int/mediacentre/news/statements/2011/breastfeeding_20110115/en/

15. Sassá AH, Schmidt KT, Rodrigues BC, Ichisato SMT, Higarashi IH, Marcon SS. Bebês pré-termo: aleitamento materno e evolução ponderal. Rev Bras Enferm[Internet]. 2014[cited 2016 Sep 3];67(4):594-600. Available from: http://www.scielo.br/pdf/reben/ v67n4/0034-7167-reben-67-04-0594.pdf

16. Maastrup R, Hansen BM, Kronborg H, Bojesen SN, Hallum K, Frandsen A, et al. Breastfeeding progression in preterm infants is influenced by factors in infants, mothers and clinical practice: the results of a national cohort study with high breastfeeding initiation rates. Plos One[Internet]. 2014[cited 2016 Sep 10];9(9):108-14. Available from: http://journals.plos.org/plosone/article?id=10.1371/ journal.pone.0108208

17. Rocci E, Fernandes RAQ. Dificuldades no aleitamento materno e influência no desmame precoce. Rev Bras Enferm[Internet]. 2014[cited 2016 Sep 3];67(1):22-7. Available from: http://www.scielo.br/pdf/reben/v67n1/0034-7167-reben-67-01-0022.pdf

18. Czechowski AE, Fujinaga $\mathrm{Cl}$. Seguimento ambulatorial de prematuros e a prevalência do aleitamento na alta hospitalar e ao sexto mês de vida: contribuições da fonoaudiologia. Rev Soc Bras Fonoaudiol[Internet]. 2010[cited 2016 Sep 3]; 15(4):572-7. Available from: http://www.scielo.br/pdf/rsbf/v15n4/a16v15n4.pdf

19. Castro MP, Rugolo LMSS, Margotto PR. Sobrevida e morbidade em prematuros com menos de 32 semanas de gestação na região central do Brasil. Rev Bras Ginecol Obstet[Internet]. 2012[cited 2016 Sep 3];34(5):235-42. Available from: http://www.scielo.br/ pdf/rbgo/v34n5/08.pdf

20. Lamy Filho F, Rodrigues MC, Correia AS, Araújo HAWP. Fatores associados ao desmame por ocasião da alta em prematuros de muito baixo peso. Rev Pesq Saúde[Internet]. 2012[cited 2016 Sep 10];13(2):21-5. Available from: http://www.periodicoseletronicos. ufma.br/index.php/revistahuufma/article/view/1318

21. Silva WF, Guedes ZCF. Prematuros e prematuros tardios: suas diferenças e o aleitamento materno. Rev Cefac[Internet]. 2015[cited 2016 Sep 10];17(4):1232-40. Available from: http://www.scielo.br/pdf/rcefac/v17n4/1982-0216-rcefac-17-04-01232.pdf

22. Ostlunda A, Nordström M, Dykes F, Flacking R. Breastfeeding in preterm and term twins-maternal factors associated with early cessation: a population-based study. J Hum Lact[Internet]. 2010[cited 2016 Sep 10];26(3):235-41. Available from: http://jhl.sagepub. com/content/early/2010/02/05/0890334409359627.abstract

23. Nyqvist KH, Kylberg E, Hansen MN, Häggkvist A, Maastrup R, Frandsen AL, et al. Neo-BFHI: the baby-friendly hospital initiative for neonatal wards. Core document with recommended standards and criteria[Internet]. Raleigh: Nordic and Quebec Working Group; 2015[cited 2016 Jul 7]. Available from: http://www.ilca.org/main/learning/resources/neo-bfhi

24. Cinar ND, Alvur TM, Kose D, Nemut T. Breastfeeding twins: a qualitative study. J Health Popul Nutr[Internet]. $2016[$ cited 2016 Sep 3];31(4):504-9. Available from: http://www.bioline.org.br/pdf?hn13061 